Marcin Drzewiecki

\begin{abstract}
SLOWNE KIERUNKI DZIALALNOSCI I ORCANIZACJI BIBLIOTEK SZKOLNYCH W POLSCE N LATACH 1773..1914
\end{abstract}

1. Biblioteki szkolne w okresie Komisji Edukacji Narodowej

Otwarcie Collegium Nobilium Warszavie $w$ rokiu 1740 o ponad 20 lat wyprzedza date tradycyjnie przyjmowana za poczatek uśmieceria w Polsce /1764 T. - Koxonadja Stanisława Aususta/ 1 . Rozpoczynajac swoje rozwazenia od otwarcia tej placóki przez pijara stanisława Konarskiego/zm.1773/ nalezy podkreslic, ż z nazwiskiem załozycie la szkoły związany jest praexom w polskim szkolnictwie katolickim. Konarski uznany jest za twócę nowoczesnego i narodowego systemu dydaktyczno-wychowawczego. Wprowadzone w Collegium Nobilium gruntowne reformy nauczania objeły po roku 1750 wszystkie szkoły pijarskie. Zmniejszono liczbe godzin lekcyjnych łaciny, wprowadzono naukę języków nowożytnych, geografii, fizyki, historiı Polski i powszechnej, arytmetyki, geometrii, poważną rolę wyznaczono języko wi ojczystemu.

Nawiazując do koncepcji pedagogicznej Jana Amosa Komeńskiego /1592-1670/Konarski wyznaczył książce zasadnicze miejsce w procesie dydaktycznym. Duży nacisk położyz na samodzielna i krytyczną lekturę ucznićn; ksiązkę widziaz jako gł́ówne źródło wiedzy. "Jako doświadczony pedagog doceniaz znaczenie dobrych podręczników, informatorów i kompendiów..."." z całą stanowczoscią i surowością przeciwstawiał się stosowaniu ksiązek przestarzałych i szkodlimych'2.

Jego "Ordynacje wizytacji apostolskiej dla polskiej prowincji szkół pijarskich" /zatwierdzone przez kapitułę w kowiczuw $1753 \mathrm{r}$./ będace podstawą prawna reformy szkół pijarskich okresliły biblioteki szkolne i czytelnictwo jako najważniejsze w dydaktyce i wy chowaniu. Zawierały przede wszystkim bardzo obszerny kanon lektu - 
ry szkolnej. Autor zalecał nauczycielom szkóx pijarskich rozwija nje u mádziezy zainteresowań czytelniczych. O stan ilościowy i jakościcwy księgozbioru obowiązani byli dbać nauczyciele. Także nauczyciele i wyznaczeni spośród nich bibliotekarze mieli troszczyć się o odpowiednią organizacje biblioteki i konserwację zbiorów ${ }^{3}$. "Ordynacje..." dotyczyły szkóz prowadzonych przez zakon pijarski. Główny trzon szkolnictwa pozostawał w gestii duchowieństwa jazuickiego, niemnjej reformy pijarów wywarły tez pewien wpływ na mode.. rnizacje szkolnictwa jezuickiego.

Wstapienie na tron Stanisława Augusta /1764/ stworzyło pomyślniejsze warunki dla rozwoju oswiaty, ale jeśli nie liczyć powołania pierwszej w Polsce czysto świeckiej Szkoły Rycerskiej /1764/, nie stanowiło punktu zwrotnego w jej dziejach. Przełom dokonaz się, gdy breve papieskie z lipca 1773 roku znoszące zakon jezuitów umożliwiło przekazanie spraw szkolnych utworzonej już 14 października tego roku Komisji Edukacji Narodowej.

Działalność Komisji Edukacji Narodowej w zakresie biblioteka rstwa oparta była na koncepcji Stanisława Konarskiego, ale miała nieporównywaInie szerszy zasieg.

Komisji podlagaly wszystkie rodzaje bibliotek, z wyjatkiem kościelnych i prywatnych, a więc: Biblioteka Załuskich, biblioteki obu Szkóz Giównych, biblioteki szkóx wojewódzkich, parafialnych /śrieckich $i$ dichownych/, pensji itd. Pierwsza z nich była biblioteka publicznz, pozostałe to biblioteki szkóz róznego stopnia. W sumie zbiory, którymi zarzadzała KEN na początku swej działalności, liczyły okołc 500 tys. tomów, z czego 350 tys. przypadało na Bibliotekę Załuskich, a 150 tys. na biblioteki szkolne 4.

Rozrzucone po całym kraju, przestarzałe i często zaniedbane ksiegozbiory, rozliczne trudności finansowe i administracyjne, burzli. we wydarzenia polityczne czasow stanisławowskich, wszystko to spa wodowało, że w ciagu dwudziestoletniego okresu działalnośi nie udało się Komisji Edukacyjnej uporządkować ostatecznie spraw bi bliotek.

Komisja Edukacji Narodowej przejmując w centralny zarząd i władanie biblioteki szkolne, ustanowiła analogiczną do systemu szkoInictwa ich sieć. Zadaniem bibliotek miało stać się wspózdziałanie w realizacji nowych zadań dydaktycznych i wychowawczych. Duży nacisk połozono na sprawy organizacyjne bibliotekarstwa szkolnego: przy każdej szkole miała znajdować się biblioteka, za którąodpowiedzialny był rektor szkoły. Rektorom zlecano dbanie o stan lo- 
kali, "konserwacji i udostępniania zbiorów oraz właściwego zaopa trzenj.e w ksiązki potrzebne do realizasji programu szkolnego. Komisja opracowywaka obowiazkowe dla kradego typu biblioteli minimalne zestawy ksiązek, przysyłała własne podręczniki, organizowała wymiane dubleśow, wprowadzała ujednolicone formy rejestracji ksiegozbio rów, starała sie zabezpieczać srodki finansowe na potrzeby bibliotek..."5 Komisja uregulowała tez status bibliotekarzy szkolnych. W pismie z roku 1790 "ustanawia siẹ urząd bibliotekarza, który albo z osób Szkoły Głównej, albo z innych uczonych osob ma być wybrany"6. przepis ten dotyczył szkół wyzszych, ale rówmiez w szkołach niżsego stopnia kandydatom na bibliotekarzy stawiano pewne wyma gania.

Komisja działała zbyt krótko, aby móc w pełni zrealizować swe postulaty. "Jednak wypracowana przez nią koncepcja i schemat organizacji bibliotek szkolnych, unikalne w ówczesnej Europie mialy stać sie trwałym dziedzictwem bibliotekarstwa polskiego"?. Według koncepcji KEN, biblioteki szkolne miały słuzyć nie tylko bezpośrednio dydaktyce szkolnej, ale rómiez ogólnenu oświeceniu.

Poniewaz zła sytuacja ekonomiczna 1 brak ksiażek unienożiwiły tworzenie odrebnych bibliotek publicznych, ich zadaniami obarczono biblioteki szkolne. Uczyniono to jednak dopiero w roku 1790, kiedy to w "Ustawie Komisji Edukacji Narodowej dla stanu akademickiego i na szkozy w krajach Rzeczypospolitej" czytamy "Jako w zamiarze rom zszorzania pożytecznych w kraju nauk postanowiła Komisja w Szkołach Głómnych katedry i lekcje dla publicznej usługi i korzyści z nauk. tak w tymże zamiarze biblioteki w Szkołach Głównych chce mieć dla pożytku nje tylko nauczycielów Szkoły Głównej i podwydziałowej, ka ndydatów do nauczycielstwa i uczniów, ale tez dia kaźdego z obywatelów któryby przy tejże bibliotece światła jakiego z ksiag cnciai zasiegnąć"8.

W latach tych, kiedy poczynania komisji paralizowane były przez narastający kryzys polityczny udało się otworzý́ dla publiczności tylko biblioteki Szkół Głównych. Biblioteki szkóz nizszego stopnia otworzono dla publiczności dopiero w roku 1812 moca ustawy Dyrekcji Edukacji 9 .

Księgozbiory, którymi przyszło gospodarować Komisji Edukacji Narodowej, jako spadkiem po jezuitach, były sprzeczre z propagowana przez Komisje ideologia oświeceniowa. Przeważały dzieła teologiczne, prawnicze, sporo było dawnych kompediow z autorów klasycznych oraz przestarzałych podręcznikow. Ksiązki te należało zarejestro wać, a nastęnie wymienić. 
Akcje rejestracji i wymieny ksiazek podjeto juz w roku $174^{i 0}$. Ksiązki wycofarie ze szkół sprzedawano na aukcjach, a za uzyskane pieniadze Komisja zakupywaza inne ksjązki i czasopisma, które potem rozsyłane były do bibliotek. Ta farma centralnego zakupu, z jednej stronystwarcaza możiwośi ujedrolicenia ksiegozbiorów szko Inych, $z$ drugiej pozwaiaza centralnyn wiadzom oswiatowym na prowadzenje w skali makro polityki gुrcmadzenia zbiorów.

Wyrazern dażenia KEN do kontrolowania zawartosic bibliotek sa tez specjalne wykazy ksiązek, które musiała mieć kazda szkoła. Wykazy te miały charakter obligatoryjny nie tyiko dla szkół, ale takze za den pensjomistiz i mistrzyni nie będzie mógł pensji. załozyć, nie opatrzywszy się w biblioteczke mała, której katalog nizej przyłączony jest..."11. Owo zarządzenie obejmowało pówniez pensje żeńskie.

Działacze Konisji zdawali sobie sprawe, iz biblioteki, szczegóInie biblioteki szkolne pracujace na rzecz miodego czyteluika, mogą być narzedziem modelowania pogladów społeczeńsiwa - i narzedzie to starali się wykorzystad. Do końca swojegü istnienia /1794/ Ko misja przejeła tylko częsciowa kontrole nad zawartościa zbiorów. DaIszy krok w tym kierınku zrobiły centralne władze oswiatowe po roku 1807.

W Księstwie Warszawskim i Krölestwie Polskim kolejno Izba Edukacyjna, Dyrekcja Edukacji i Konisja MRiop zdobywały prawo coraz szerszej ingerencji w zawartość księgozbiorów. Głównymi źródłami pow wiekszania zbiorów były: dary i legaty pośmiertne, zakupy z opłat szkolnych, zakupy z funduszów uzyskiwanych za sprzedawane zbiory pojezuickie, poaustriackie, popiuskie oraz zakup centralny.

O ile wpływ KEN na skład zbiorów polegał głównie na sporzązaw niu katalogów wzorcowych i prowadzeniu zakupu centralnego, to in $\infty$ stytucje Ksiestwa i Królestwa posiadały pełne prawo kontrolowania indywidualnych zakupów szkół. Listę darów właczanych do biblioteki przesyłano najpierw do Warszawy do zatwierdzenia, a zakupy szkóz mogły być realizowane dopiero wtedy, gdy poszczególne tytuły uzyskały aprobatę władz. Politykę gromadzenja zbiorów bibliotek szkoInych w tym okresie charakteryzuje M. Łodyński następująco: "Szlo przy tym nie tylko o ogólne zapełnienie bibliotek, ale też i o dobór książek odpowiadających progranowi szkolnemu oraz szczególnie podkreślanej przez Komisje WRiof potrzebie pewnej postawy obywatelskiej uczniów"12.

Nie tylko ingerencja w polityke gromadzenia wskazuje, ze władza państwowe dążyły do kształcenia "postawy obywatelskiej" wczniów 
przez biblioteki. Inny tego dowodem jest crganizacja zewnętrzna ezkoInicrwa zdązająca do coraz większej centralizacji. Gdy KEN podlegały bezpośrednio tylko Szkoly Głomne, któnym z kolei podporządkowane były szkoły wojewódzkie, powiatowe i elementarne - to późniejszym magistratumom wszystkie typy szkól podlegaly bezpośrednio. Przy tym KEN byla organem samodzielnym, odpowiedzlalrym tylko przed sajmen, podczas gdy instytucje oświatowe Księsiwa i Królestwa przez cayy nienal czas swego istnienia wchodziły w skład Mini sterstwa Spraw hewnetrznyoh ${ }^{13}$.

Najważniejszym osiągnięciem KEN na polu bibliotekarstwa szkolnogo było ujęcie tej problematyki w skalj cazego kiaju. pozskie władze oświatowe tworząc konkretny program dziaiania bibijotek były w Europie pionierami. Pierwsze polskie rozporzarizerie dotyczace bi bliotek szkolnych zostało opublikowane w warszawie w roku $1774^{14}$, podczas gdy analogiczne akty urzedowe Europie Zachodniej notujemy: we Francji w roku 1792, Holandii w 1806, Austrij $1349^{15}$,

\section{Lata niemol1 1795-1914}

Biblioteki szkolne w Ksiestwie Warszewskim i Królestwie Polskim /1807-1831/

W okresie Ksiestwa Warszawskiego odżły idee Komisji Edukacji Narodowej realizowane przez centralną władzę oświatową Księstwa Izbę Edukacyjną, przekształconą w 1812 roku w/Dyrekcję Edukacji Narodowej. Pracę Dyrekcji w Królestwie Polskim podjęla następnie Komisja Wyznań Religijnych i Oświecenia Publicznego, na której, czele sianął Stanisław Kostka Potocki. kontynuując suą działalność roz . poczęta w Izbie i. Dyrekcji.

Przystosowując wytyczne KEN do zmienionych warunków społeczno-politycznych władze oświatowe Księstwa i Królestwa zwrócily należytą uwagę na organizacje i rozwój bibliotek szkolnych. Scentralim zowanie kierownictwa wszystkich szkóz usprawniło problem nadzoru nad szkołami, a w tỵ i nad bibliotekami. Zadbano przede wszysikim - stan zbiorów, które aktualizowano i systematycznie powizkszano ${ }^{16}$. W myśl przepisów bibliotecznych ${ }^{17}$, które były częscią składową ogóInych przepjsów szkolnych, rektor szkoły czuwał nad ogólnym stanem biblioteki. Corocenie był zobowiazany skzadać wadzom centralnym sprawozdasia z pracy biblioteki. Rektor szkoly zlecał bezpośredni 
nadzór nad biblioteką jednemu z nauczycieli. Przpeisy dla szkóz departamentowych /wojewódzkich/ ogłoszone przez Dyrekcje Edukacji Narodowej w 1812 roku zawierały m.in. rozdziały mówiace o "Urzadzeniu bibijioteki i archiwuin szkoły". Biblicteka byla przeznaczona dla nauczycieli i uczniów klas wyzszych. Przewióywano udastgpnianie zbiorów osobom spoza szkoły - a wieo nadawano bibliotece szkolnej także charakter biblioteki pubïicznej. Udostepniano zhıory w formie dwojakiej: wypożyczano na zewnętrz oraz na miejsou/prezencyjnie/ w czytelni, czynnej przynajmniej 2 razy w tygodniu ${ }^{18}$. W czytelni dyżur bibliotekarza był obowiązkowy.

Uczniowie klas nizszych posiadali osobry kaigozbiór, ktory obejmował nie tyıko obowiązkową lekturę, ale także książki "umyślnie dla młodzieży pisane".

Analizujæc urzędowe instrukcje dotyczące bibliotek szkolnych tego okresu M. kodyński zwraca uswaqe na czytelnictwo uczniów, któremu władze oświatowe poświęcazy wiele uwagi. Za stan czy tolnictwa byli odpowiedzialni nauczycieje wszystkich przedmiotów. Uczniowie klas wyższych korzystali na zasadzje wolnego dostępu do półek, klasy niższe wypozyszały przy pomocy niuczyciela-bibilotekarza.

Wiele starań poświęcąy wácize Keięstwa i Królestwa sprawio uzupełniania ksiegozbiorów. Gospodarowano starannie dubletami. wizytatorzy pomagali w prowadzeniu waściwej polityki gromadzenia zbiorów.

Wzrost ksiegozbiorów szkolryycin przypada na czasy królestwa, do czego przyczyniła sie lepsza niz w Księstwie Werszawskim sytuacja finansowa kraju. "Według danych z roku $1826 / 27$ najzasobniejsze zbiory posiadały następujące biblioteki szkół wojewódzkich lub wydziałowych: w Lublinie /4140 tomów na 463 uczniów/, w Kielcach /3060 tomów na 436 uczniów/ na dalszyñ niejscu znalazły się biblioteki szkoł iv Płocku, Szczuczynie, Pułtusku, Pinozowie, Radomiu, Lqczycy i Sejnach. Wszystkie liczyły powyżej 1000 tomów... Znacznie gorzej natomiast przedstawiały się księgozbiory szkół podwydziałowych, np. tykocińska miała tylko 130 ksiąg na 69 uczniów, a w Skępem - tylko 48 ksiąg na 93 uczniów 19.

Wiele uwagi poświęcały władze oświatowe Królestwa sprawie doboru książek do bibliotek szkolnych. W roku 1820 wydano specjalne zarzadzenie podajace wzorcowy katalog dla bibliotek szkół wojewódzkich 20 . Uwzględniał on wiele informatorów encyklopedyczno-słownikowych: zawierał też ogólną wskazówkę, iż oprócz dzieł w nim wymienionych należy kupowá na bieżąco odpowiednie nowości wydawnicze, a stare wydania zastępować nowymi. W roku 1825 Komisja Wyznań Religijnych 1 
Oświecenia Publicznego wydała pismo do rektorów szkół, aby spisy ksiażek przedkładane Komisji Rzadowej do aprobaty były sporzadzane grupowo przez nauczycieli na radach pedagogicznych w celu uwzgle ónienia każdego przedmiusu wykładanego w szkole ${ }^{21}$.

Kontrola prawidzowości doboru książek była podyktowana nje cylko troską o proces dydaktyczny, ale takje cenzura polityczna związaną z naciskiem Rosji.

Biblioteki szkolne okresu Królestwa Polskiego, oprócz zadań dydaktyczno-wychowawczych wobec uczniów, spełniały doniosłą rolez wobec całej grupy inteligencji polskiej. W związku z coraz silniejszym naciskiem politycznym Rosji społeczeristwo podejmowaxo tworzenie róznych zrzeszeń i towarzystion jako ośrodków rozwoju i zachowa.. nia ciagłości kultury polskiej. Powstawały one nie tylko w warszawie, ale i $w$ innych miastach jak w Płocku, Lublinie, Siedlcach, Radomiu, Kaliszu, Kıelcach. Biblioteki szkolne były wyposazane w Iiczne dary - często o charakterze publikacji naukowych. Niektóre z tcwarzystw kulturalno-naukowych łaczyły swe zbiory z miejccowa biblioteką szkolną przakazując jej zarazem swe publiczne zadania 22 /np. uczynilo tak w roku 1817 Towarzystwo Instytutu Bibliopolicznem go w Lubininie, przekształcone w roku nastepnym w Towarzystwo Przyjaciół Nauk, podobne zjawiska miały miejsce w Płocku, Kielcach,Pińczowie, Siedlcach/.

Fomyslny rozwój oświaty, a w nim i bibliotek zostaz przerwanyw roku 1820. Zmiana polityki caratu wobec Królestwa, której symbolsm w zakresie szkolnictwa stało się odwołanie Potockiego i mianowanie ministrem Stanisława Grabowskiego, odbiła się równiez na bibliote kach. Poddano je kontroli władz działających niezgodnie z intere sem narodowym. Ostatnie dziesięć lat przed powstaniem listopadowym upłynezo w walce o utrzymanie dotychczasowych zdobyczy i chociaz sytuacja szkół i ich bibliotek stawała się coraz trudniejsza, to prawdziwy ich upadek nastapił dopiero po klęsce powstania Iistopadowego.

Biblioteki szkolne w latach 1773-1830 spełniały 3 funkcje, z których ostatnia była wypadkowa konkretnej sytuacji politycznejPoIski tego okresu:

1/ wypełniały tradycyjną, usługową funkcje w stosuriku do potrzeb nauczania szkolnego,

2; służły jako placówki kulturalne środowisk pozaszkolnych,

z. wykorzystywane były /szczególnie w okresie sejmu czteroletniego/ jako narzędzie walki poiitycznej i jeden ze środków kształtowania poglądów społeczeństwa. 
l-ata 1831-19:4 pod rzadami caratu

Okras względnego Iiberalizmu skończyt się wraz z upadkiem pow stania listopadowego. Nauka j szkolnictwo znalazły się wisod dziew dzin życia dotkniętego szczególnio brutalnymi represjami: zamknięto Lnjwers\%tet Warszewski i Towarzystwo Przyjacioz Nalsk, we wszy = stkich szkołach wojewódzkich rozwiazano te klasy, których uczniowie trali udział. w powstaniu, usunieto wszysikich podejrzanych nauczycieli, zniesiony został wynikajacy jeszcze z przepisów księ . stwa Warszawskiego udział spoleczenstwa w kierowaniu szkołami.

Ogłoszona w roku 1833 ustawa szkolna powaznie obniżya pozion om światy. Szkołom elementarnym - jako placówkom, których zadaniem bylo tylko wychowanie religijno-moralne, nauka pisania i czytania oraz podstawowych działari arytmetycznych, zapewniono znosne warunki. rozwoju, szkolyy średnie znalazły się w znacznie gorszym połozeniu. $z$ nich właśnie, obok uniwersytetu wywodzili sie najbardziej ideowi uczestnicy powstania. W roku 1831 Mikołaj I pisał do gen.Paskiewicza: "Poniewaz edukacja była zła i jej to wiłaśnie nalezy przypisać skłonność młodzieży do byłego buntu, należy na tę dziedzinę zwró cić największą liwage..." 23.

Zlikwidowano drożność i jednolicość szkóz, w celu ograniczenia Iiczby uczniów podniesuono wpisowe, zniesiono wykłady z historii i geografii. Polski. Obok tych Jawnych zarządzeŕ opracowano/1834/tajna instrukeje wprowadzajaca kary za najlzejsze nawet przerinienia

Na efekty tak pojmowanej polityki oswiatowej nie trzebabyłodługo czekać. Na początku lat sześćdziesiątycn analfabeci stanowili. ponad 90\% ludności Królestwa 24.

Akcja rusyfikacyjna w stosunku do bibliotek, którą rozpoczęto wywiezieniem do Petersburga zbiorów uniwersytetu i Liceum Warsza wskiego, cbjęa również hibliotekę byłej szkoły pijarskiej. Inwe ntarz biblioteki świadczy, że w ciagu około 20 lat ijość ksiązek zmniejszyła się pięciokrotnie: w roku 1840 zbiory biblioteki liczy Iy zaledwie 1335 dzieł w 2679 voluminach ${ }^{25}$. Rosyjskie podręczniki stanowiły większą częśc doetarczanych bibliotece przesyłek. "Czy .. szczenie ksiegozbioru" polggało na usuwaniu 2 kategorii ksiązek. Do pierwszej nalezały te, które "jako szkodliwe podlegaja zakazowi cenzury". Zaiiczano tu wszystkie polskie czasopisma jak: "Pamietnik Lwowski", Dziennik Nadwiślański" i"Gazeta Warszarska" . W katego- 
rii drugiej "Koiązek zupełnie dia bibliotek niepotrzebnych" obok dziel Kania, Machievellego, Staszica znalazly sie tez pomoce do naw uki jozzyków obcych ${ }^{26}$.

Represje,jakie spadzy na szkolnictwo po klęsce powstania sty w czniowego, poprzeaził icrótxi okres wzglednej pomyśanośsi w latach 1861-1863, kiedy car nękany buntami w centralnej Rosji i na lkrainie zmuszony /w myniku wojny krymskiej/ szuká porozumienia z Fraw ncja żądająca zlagodzenia polityki wobec Polaków, wreszcio w obewie przed rozszerzeniem sję demonstracji, jalie niały miejace w Warszawie w lutym 1861 roku, przyzal Królestwu szereg koncesji, któm rymi objeto tez szkolnictwo.

W iniejsce Okrø̧gu Naukowego varszawskiego przywrócono niezależá od ministerstwa w Peiersburgu Komisje WRiOP, a w naju 1862 car zatwierdzil nową ustawę szkolria.

Przygotowana w tym okresie przez Aleksandra Wielopolskiego i Józefa Korzeniowskiego "Ustawa o wychowaniu publiczným w Królest wie Polskin"27, chociaz kompleksowo rozwiązywaza sprawy szkolnic twa, nie zmienila jednak sytuacji bibliotelk szkolnych. Na 352 artykuly, jakie "Ustawa. .." Zawierała, tylko dwa poświecono bjbliotekom. Wart przytoczenia jest art. 359, w którym znalazły się sformułowania świadczące o kierunliu planowarej roorganizacji bibliotek: "Bibliotem ka Cłówna i viszystkie biklioteki przy Zakładach Naukowych uważaja się za jedna całość i zostają pod zwierzchnim zawiadywaniem Dyre ktura Horırowego Ejbliotek w Królestwie, którego Dyrektor Główny prezydujacej w Komisji Rządowej Wyznań Religijnych i Oświecenia Publicznege z pomiędzy ludzi znanych z nauki i zamiłowania w rzeczach bibliotecznych do nominacji Namiestnika przedstawiać będzie" 28 .

Fostulat jednolltej sieci bibliotek i fachowej nad nią opieki był cennym osiągnieciem Wielopolskiego, ale w sferze teorii - praktyczną jego realizację uniemożliwił wybuch powstania styczniowego.

Po jego kذદ̨sce władze rosyjskie podjęły intensywna akcję unifikacyjną, której celem była ostateczna likwidacja odrébności Królem stwa Polskiego. Zniesiono autonomiczne dotąd centralne walze Królestwa: Sekretariat i Radę Stanu oraz Radę Administracyjną. Przywrócono Naukowy Okreg Warszawski, na czelé z kuratorem podiegłym bezposiradio Ministerstwli Oświccenia Fublicznegow Petersburgu. Zakazaro zakiadania odrębych stowarzyszeń gospodarczych, kuItura Inyon j. naukowych. Ograniczono prawo druku w jezyku polskim.

w' zakrssie oswiaty najbardziej intensywne zabiegi weryfikacy 
jne zastosowano znowu wobec szkół średnich. Ukazen cesarskim z roku 1669 rosyjski stał się jezzykiem wykładorym we wszystkich szkozach. Swałtowa antypolska polityka caratu po roku 1864 wywolała odruch obrony społeczeństwa. obrone polskiej oświaty podjeto przez tworzenie tajnych bibliotek uczniowskich oraz pras€ samokształceniowa w oparciu o biblioteki instytucji oswiatowych pozaszkolnych.

Okreslenie liczby. wielkosci i charakteru tajnych zbiorów uczniowskich wydaje się dzisiaj niemożlibe. Należły one do organizacji ukrytych nie tylko przed wàdzani, ale i przed nite wíjemniczoiymi uczniami. Brak o nich wiadomości urzędowych, a w literaturze pamiętnikarskiej autorzy, zaznaczajac istnienie biblioteki, zajmuja się przede wszystkim opisywaniem zwiazzanych z nią perypetii. Ponadto opracowaria dotyczace przełomu XIX i XX wieku, szczególnie poswięcone strajkowi szkolnemu 1905 roku, mimo ze liczne i drobiazgowe, tylko wyrywkowo poruszaja sprawy tajnych bibliotek.

Rozkwit nielegainyci bibliotek nastapiz na przełomie XIX $i \quad X X$ wieku. charakterystyke j.ch znajdujemy duzo wczesniej, bo w dekla racji Filomatów z roku 1815, gdzie czytamy:" zbiór takowy nie be dzje zależa na wielkiej liczbie ksiazek, lecz zawierac musi ksią. żki we wszystkich gałeziach nauk używane w obcych narodów. a zatem zbiór winien byc systematyczny i pesny" 29 . Ksiegozbiór tajnej bi blioteki mıał więc być operatywny, a przy tym wszechstronny i oczywiście wyposażony w İteraturę pig̣knạ, narodową i dzieła zwalcza jace oficjalne a szkodliwe poglądy zaborców. Sprostać tym postuiatom nie było łatwo, nie tylko ze względu na restryksje policyjne, ale takze warunki finansove. Finanse obciążły przeciez kieszen uczniowską.

Gwałtowny rozwój nieiegalnych bibliotek wiąze się z ustąieniem Aleksandra Apuchtina /1822-1904/, zaciekiego rusyfikatora szkolnictwa w Królestwie, ze stanowiska kuratora warszawskiego okregu szkoInego i intensyrikacją ruchu samokształceniowego bezpośrednio przed rokiem 1905.

Charakter polityczny tajnych księgozbiorów zmieniał sie wraz z ewolucją ruchu szkolnego. Jego radykalizacja od bezpartyjnych or ganizacji o zabarwieniu patriotyczno-postępowym do kółek socjali stycznych jest dla nas o cyle istotna, ze wraz z nią powiększał się zasięg oddziaływania zbiorów: początkowo ich użytkownikami byli wy łacznie uczniowie, lecz w miare narastania nastrojów rewolucyjnych wśród czyteiników znaleźli sie też młodzi robotnicy i rzeniéslnicy. Dowoden znaczenia, jakie przykładały nielegalne organizacje u- 
czniowskie do rozwoju czytelnictwa, jest odezwa komitetu zrzeszajacogo kółka samokształceniowe szkół warszawskich "W celu rozbudze nia wśród młodzieży szkolnej zywszego zajęcia się wspózczesirym prądami i objawami życia społecznego /Komitet/ rozpowszechnia wśród młodzieży szkolnej ksiązki i pisma nielegalne"30. Tajre bibliote ki uczniowskie istniazy także poza Warszawą: H. Falkowska ${ }^{31}$ wymie nia Łęcycę, Płock oraz Piotrków Trybunalski.

Skromne mozliwości organizacyjne i finansowe sprawiły, że zakres prowadzonej przez młodziez pracy samokształceniowej by ograniozony. Na znacznie szerszą skalę działalność w tym kierunku prowadzily "dorosłe" instytucje oświatowe powstające w Królestwie w osta tnim ćwiercwieczl XIX wieku. Część z nich posiadała równiez własne biblioteki. Nie sposób wymienić tu wszystkich społecznych stowarzyszeń oswiatowych Królestwa. Jak podaje K.Kona!ski32, samych zrze szeń szkolnych naukowych i ogólnokulturainych było około 300 - od najważniejsaych jak Unjwersytet Latajacy, Kozo Oświaty Ludowej, Towarzystwo Tajnego Nauczania, Towarzystwo oswiaty Narodowej, po marginalne, np. Towarzystwo Schronienia dla Służących czy Towarzystwo Kobiet kulturainych.

Najstarszym tego typu związiem było Warszawskie Towarzystwo Dobroczynności. Praca na polu bibliotek była tyiko jednym z kierunków działalności Towarzystwa - założony w 1858 roku crzy WTo Wydział czytelni miał za zadanie: "przez bezpłatne wypozyczanie ksiäżek przyczynić sie do rozwoju umysłonego i moralnego niezamożnej klasy Iudności m. Warszawy oraz nieść pomoc niezamożnej młodzieży, k£ztałcącej sie w niższych, iak i wyższych zakładach naukowych przez Lłatwjenie nabycia, wypozyczenia na czas całorocznego kursu bezpłatnie ksiazzek szkolnych ${ }^{33}$. Pierwszych sześć bibliotek ufundowa nych zostało w roku 1861, z czasem ich liczba doszła do kilkudziesięciu. W koŕcu wieku ksıegozbiory czytelaj WTD uiegły takiej rozbudowie, że przekroczyły pierwotny cel, jakim było zaopatrywanie najbiedniejszej ludności w ksiązki "moralne i pouczające.34. Zywy ruch wyjawniczy tego okresu pozwolił wyposazyć biblioteki w dzieła z zakresu przyrodoznawstwa, filozofii, zagadnień społeczno-ekono micznych. Zmianom księgozbiorów towarzyszyły zmiany składu czytelników WTD.

W latach sześćdziesiatych uczniowie stanowili tylko 9.5\% użytkowników, 32 , 8\% rzemieślnicy, 22,4\% robotnicy fabryczni, 10,4\% urzednjcy, $19 \%$ służba domowa, 5,9\% kupcy. W latach dziewięćdziesiątych wśród kơrzystajacych byıo 64\% uczącej się młodziezy, w wię- 
kszosici prawdopodobnie uczestrików tajrych kółek samokształceniom wych, a tylko $36 \%$ przypadało na nłodziaj robotnicza i rzemieslni$\mathrm{cza}^{35}$. Mamy więc do caynienia z wyraźna ewojucja ksiggozuioru od poziomu rajoaroziej przystepnego do popu?arnonaukowego, a nawet naukowego, czytelników od ludzi. o niskin /ozesto zadnym/ poziumie wykształcenia, do młodej inteligencji. Kierlinek ten został zahamowany, gdy w roku 1899, na skutek konfliktów w zarzadzıe wTD, do czytelń wkroczyła policja i po rewizji ksiegozbiorów areszto wano kierownictwo Wydziału Czytelni, a dzialalnośc bibliotek zo staia ograniczona az do 1905 roku.

Największą z polskich instytucji oswiatowych w Krolestwie by Ła Polska Macierz. Szkolna - załozona w roku i905, zalegaiizowana $w$ nastepnym roku postawila sobie za cel połaczenie wszystkich tajnie dolied prowadzonych prac oświatowych? 36.

W krótkim czasie PMS zrzeszajạca 150 tys. członków i około 800 kóxek stała się faktycznym ministerstwem oswiaty, konkurencją dla oficjalnego kuratora szkolnego. PMs obejmowała swoim wpiywem cały system szkolny i do tak szerokich funkojj. była dostosowaria stru ktura organizacyjna.

Bibljotekami zajmowała się Sekcja Czytelniana Wydziału oświaty Ludowej. Pod kiarownictwem kazimierza Chelchowskiegoopracowywamo w niej katalogi bibliotek wiejskich, wydawano odezwy w sprawie czycelnictwa ludowego, dogladano bibliotek, których w 1907 proku PMS miała ponad 500. Biblioteki Macierzy Szkolnej uzupolniały sieć różnego stopnia sziḱly, przewaznie jednak najprostszych dwuklasowych szkúłek wiejskj.ch, i stąd ich funkcje sprowadzały się do wspomagania na szeroka skaię prowadzonej przez PMS akcju przecj.w anaIfabetyzmowi. PMs wywarła duzy wpływ na politykę biblioteczna lat $1918-1939$.

Bi.blicteki szkolne pod rzadami frus i Austrii /1795-1914/

Polityka oswiatowa Prus i Austrii w okresie porozbiorowym ksztaztowała się zależnie od sytuacji politycznej państw zaborczych.

Po rozbiorach w latach 1795-1796 pruskie władze oswiatowe przeprowadziły na terenie Wielkopolski i Pomorza badanie stanu tamtejszych szkół zarówno średnich, jak i elementarnych. Stwierdzonodobry stan szkół średnich; niektórzy z wizytatorów byli za utrzymaniem, jako wykładowego - jezyka polskiego: Krytyce poddano natomiast 
stan szkół elementarnych; zwrócono uwagę na ich ma a a ilośc w sto sunku do potrzeb.

Postanowiono, podobnie jak w całym penstwie, objąó szkolnictwem elementarnym szerokie warstwy ludności miejskiej i wiejskiej. Po zostawiono, na razie, vi szkołach tych jezzyk polski - jako wykzadowy ${ }^{37}$. Starano się natomiast zniemczyc nauczycieli tych sziḱł.

W Prusach Wschodnich i na Mlasku stosowano surowe kary za uży wanie jezzyka polskieģo, ale na ziemiach Wielkopolski, chociaz od roku 1842 wprowadzono jezyk niemiecki jako jeder z przedmiotow, um trzymywazo sję nauczanie w języku polskim az do czasúw Bismarcka.

o bibliotekach ówczesnych szkół elementarnych w Wielkopolsce wiemy niewiele. Pruskim władzom oświatowym zalezało na tym, by likwidować analfabetyzm, Uwazano bowiem, iż bez nauki jezyka ojczyste go nie można wprowadzać jezyka niemieckiego do szkói elementarnych "We wsiach powstawazy samcrzutnie biblioteczki szkolne, kompleto wane staraniem miejscowach polskich organizacji oswiatowych lub pojedynczych obywateli. Skromne zbiory wiejskich szkółek słuzyły jednocześnie czytelnikowi dorosłemu i stawały się bibliotekami p:1blicznymi. Nawiażywano w ten sposób do dawnej tradycji bibliotek szkolnych:38.

Cdmiennie niz w szkolnictwie elementarnym przedstawialy się zhiory polskie w szkołach średnich księstwa Poznariskiogo. W kla sach nizszych przewazaz jezyk folski jako wykzadowy, ale w klasych wyżzych zastępowano go niemieckim. Az do powstanio listopadowgo kurs pruskiej politykj oswiatowej w stcsunku do księstwa Foznan skiego by dość igledny. W Lesznje obok klas nienieckich utrzymano klasy poiskie. Gimnazjum im. Niarii Magdaleny w Poznanili Zachom walo charakte polski, mimo że fundusze rzadowe, przeznaczane na uzupełnienie zbiorów biblioieki szkolnej, wykorzystywano wyłacz .. nie na książki niemieckie.

Wiefszy nacisk germanizacyjny rastosowaly wadze purskie w sto. suniru do szló 1 na Pomorzu. Gimnazjun w Chelnnie przeksztalcono w vyzszą szliołe niemiecką; a juź od roku 1784 zakupywaro lo jej bj. bliotelci wyłącrnie drieła w tym jerzyku.

Na mocy rozporządzeń pruskich władz oswiatowych, w latuch 1324-1825 przeprowadzono selekcje ksiązek w dzialach uczniowskich bibliotek szkolnych. W efekcie tejakcji ze szkół w Wielkopolsce i na Pomorzu wycofano wiele ksiażek polskich. W 1825 roku rozporzadzeniem pruskiego ministra spraw wewnetrznych zakazano uczniom gimnヨzjalnym wypożyczania książek w publicznych bibliotekach poza szkolnych ${ }^{39}$. 
W zaborze austriackim szkolnictwo elementarne znalazło się wytuacji bez porównania gorszej niz pod rzadami pruskimi. Galicja odpadıszy od Rzeczypospolitej juz przy pierwszym rozbiorze nie by ła objęra działalnością Komisji Edukacji Narodowej. Nieliczne szkóiki parafialne znajdowały sie w stadium upadku. Rząd austriacki ow bnizy poziom oświaty ludowej prowadząc jednocześnie politykę germanizacji. "O jakichkolwiek bibliotekach w szkołach elementarnych w tym okresie nic nie wjadomo" 40 .

Upadek ruchu rewolucyjinego $z$ lat 1848-1849 spowodował nasilenie kursu antypolskiego $w$ zaborze pruskim. Ustawa z 1854 roku obniżyła stopień organizacyjny szkół wiejskich ${ }^{41}$, aw miejskich szkołach elementarnych zwiększyła liczbę godzin przezraczonych na rauke je zyka niemieckiego. Mimo oszabienia aktywności w zakresie ruchu kuIturalno-ojwiatowago, na Slasku i w Wielkopolsce grupa pedagogów j działaczy społecznych/Józef Lompa, Emanuel Smółka, Ewaryst Estkowski, Paweł Stelmach/prowadziła liczne prace na polu krzewienia kultury i oswiaty. Jedna z form pracy były czytelnie zwiazane ze szkoła nie tylko przez osobe nauczyciela-bibliotekarza, ale i lolaalowo. Mieszcząc się w szkole pełnizy funkcje czytelni dla doro . słych, a dla dzjeci - rolę biblictek szkolnych.

U schyłku lat pięćdziesjatych nastąpiło cześciowe złagodzenie ucisku politycznego i jednoczesne ożyienie ruchu naukowego /utwo. rzenie Poznariskiego Towarzystwa Nauk/. Sprawy oświecenia ludu, nauki i kultury znalazły się ponownie w centrum uwagi postepowych działaczy społecznych i były coraz częściej poruszane na łamach prasy.

Zjednoczenie Niemiec, osiagniete przez Bismarcka dzięki pruskim zwyciestwom militarmym, przyniosło Polalsom Wielkiego Ksiestwa Poz nańskiego, Pomorza i Sląska nową falę germanizacyjną. Prowadząc wa1 lkę z polskoscią Bismarck przez cały okres swych rządów/1862-1890/ dokonywał gemanizacji szkolnictwa ludowego i średniego w prowi ncjach zamieszkałych przez ludność polską. Od 1887 roku zniesiono naukę czytania i pisania w jezyku polskim, zabroniono także, dzieciom $w$ tym jezyku rozmawiac. W celu walki o zachowanie polskości, podjeto coraz intensywniejszą pracę w jawnych i tajnych organizacjach oświatowych. Polskie Towarzystwo Oswiaty Ludowej, roz wiązane przez władze niemieckie w okresie "kulturkampfu", zostało reaktyivowane przez utworzone w 1880 roku Towarzystwo Czytelni Lu dowych. TCL w swojej działalności wysunęło na plan pierwszy zakładanie po wsiach i miasteczkach bibliotek i czytelni oraz wspieranie wydawnictw i czasopism dla ludu. 
Wielkopolskie organizacje oswiatowe objezy swym zasięgiem rów nież ziemie Slaska oraz Warmie i Mázury.

Po upadku Bismarcka w roku 1890 nastapiło chwilowe osłabienie nacisku germanizacyjnego i. Władze pruskie zezwoliły na nauczanie dzieci jezzyka polskiego. Jednak w okresie działalności Hakaty, prześladowania jzzykowe doprowadziły do głośnej sprawy wrześnienskiej, a następrie do strajku szkolnego /1906-1907/.

W Wielkin Keiestwie Poznańkim szlolniotwo średnie niemczono syo stematycznie juz w okresie przedbismarkowskin, a bczwzględnie zo stało zgermanizowane po roku 1874. Akeja germanizacyjna przeprowadzone ponacto na Pomorzu $三$ Slessku rile pominęła równieź biblictek szkolnych. Przerwanie dopływu ksiazek polskich przy jednoczesnych obfitych dotacjach rządowych na ksiązki nienieckie przyczyniło się do upadku zbiorów polskjch. "uziady uczniowskie bibliotek gimna zjalnych w Wielkim ksiestwie Poznańskim, ra Ponorzu, Slasku, warmi i. Mazurach zswierały aż do roku $18 \partial E$ wyłacznie ksiązki niemieckie. Natomiast w dziazech neuczycielokich - mimo wielu przypadków usuwania ksiazek polskich - pozostało jeszcze wiele cennych drukow polskich lub Polski dotyczacych.. Natomiast udostepniany uczniom główny zrąb zbiorów miaI charakter wybitnie niemiecki..." 42 .

Podobnie jak w innych zaborech na przełonie XIx/XX wieku, w wielu gimnazjach wielkopolskich istnjaly tajne kola młodzież polskiej Trowarzystwo Filomatów, Stowarzyszenie im. Tomasza Zana/. Koła te miały własne biblioteki.

Szkolnictwo srednie Galicji nie było w lepszej sytuacji. Kolegia pijarskie zamknięto po pierwezym rozbiorze, a poziom nielicznych pozostałych szkćl średnich byi bardzo niski.

Najpomyślniejsze warunki dia rozwoju naszego szkolnictwa ist niały w Rzeczypospolitej Krakwwskiej. W bezpłatnych szkołach elementarnych nauczano po polski: tworzono tez wich bibiioteki.

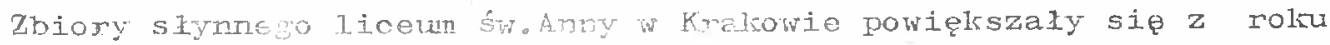
na rok.

Niepowodzenia nilitarne Austrii Kleska w wojnie wzoskiej 1859 roku i pruskiej 1865 roku/ oriz wemnętrzne konflikty w panstwie zinusily zaboroe do zmiany systemu rzadzenia oraz nadania Polakom swobód politycznych I kulturalnych. Po otrzymaniu przez Galicje autonomii otworzyty sie duze mozliwosci dla rozwoju polskiego szkoInictwa. Utworzona w 1867 roku Rada Szkolna krajowa była odrębną władza oswiatowa. Stosunki szkolne w zaborze austriackim układały się dia polaków bez porownania pomyślniej niz w zaborze rosyjskim 
i pruskim; najwieksze osiagniecia notowano w zakresie szkolnictwa srecuiego. Znacznie gorzej wyglądał stan szkolnictwa ludowego. zwkaszcza wiejskjego.

Jet awa $z$ dnia 25 czerwca 1573 roku 43 "O władzach nadzorczych miejscowych i okregowych szkóz. ludowych" uwzględniła sprawy bibliotek szkoinych. Rady Szkolne Okręgowe nadzorowały biblioteki szkolne i biblioteki dla nauczycieli, a Rady Szkolne Miejscowe były odpowiex dzialne za stan ksiegozbioru. W praktyce jednak, w uibliotece sziroty biednej wsi galicyjskiej znajdowały sie elementarze, czytanki j. wypisy, a samo istnienie biblioteki było zalezre od dobrej woli nauczyciela bądz od utworzonego w 1891 roku. Towarzystwa Szkoły Lu dowej J.ıb innej organizacji oświatowej. TSL, zakładając szkoły, czytslnie i biblioteki wiejskie, rozwijało czytelnictwo dorosłych,jak i dzieci, dzięki częstej lokalizacji czytelni i bibliotek w szko 1 actio

Lepszy stan bibliotek notowano w szkolnictwie średnim. Uważajac gimnazja za szkoły elitarne Rada szkolna krajowa zwróciła szczegóInE uwage na problem czỹelnictwa ich uczniów i nauczycieli. W kazdym sprawozdaniu dyrektor szkoły podawał dokłacne informacje o aktualrym stunie biblioteli, a czesto szczesósowe dane statystyczne i opison o wykorzystaniu ksiggozbioru szkolnego.

Funkcje bibliotek szkoinych w XIX wieku zostały wypaczone przez sytuacje polityczna Polski. W okresie zaborów biblioteki odegrały istotrą role jako placówki podtrzymujace ciąłośc kultury polskiej, ale i.h znaczenie jako ośrodków wspomagających proces nauczania zmniejszyło sier

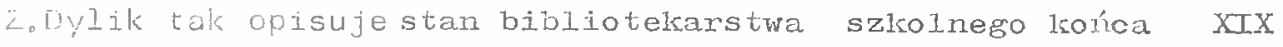
wieku: "Uwaga ówczesnych pedagogów koncentruje się głónia na zaopatrzeniu biblioteki szkolnej w ksiązi, odpowiednim doborzeiprom dukcji joblych pozycji dla mlodziezy. W zasiegu ich zainteresowa nia znajduje siẹ też wypozyczanie i kontrola czytelniciwa uczniów. Biblioteki nie traktuje się jeszcze jako odrębnej pracowni ogólno ksztalcạcej, niezbednej przy rauczaniu wszystkich przedmiotów i wychowaniu szkolnym. W zwiazku z tym nie wysuwa sie potrzeby fa chowej obsady pexsonalnej, ograniczając sie do postulatu, by ksiązki wypozyczali nauczyciele jezzyka polskiego lub innego, ubolewajac jedynie, ze za te prace bibliotekarz nie otrzymuje wynagrodzenia" 44

Polskie biblioteki szkolne lat 1905-1914 spełniały przede wszy stkim funkcje polityczną. Ich użytkownikami nie byli wyiacznie u- 
czniowie; zasięg oddziaływania zbiorów poszerzą się w miarę narastania nastrojów rewolucyjnych na inne grupy spoleczne. Wśród użytkowników tych bibliotek znaleźli się młodzi robotnicy i rzemieślnicy.

Działanja wojenne pierwszej wojny swiatowej spowodowały kolejne spustoszenie wśród ksiegozbiorów szkolnych.

P $r$ z y $i s y$

1 Historia Polski. Pod red, T,Manteuffla t.2, sz, 1, Warszawa 1956, s. 365 ,

2 B. Bieńkowska, Staropolski śmiat ksiazek, Wroczaw 1976, s. 159.

3 s. Konarski, Lstawy szkolıe, Kraków 1925.

4 M. Lodyński. U kolebki polskiej polityki bibliotecznej, Warszawa 1935. s. 26.

5 B. Bieíkowska, ..., o.c, s. 137 .

6 Ustawodawstwo szkolne zo czasow Komisji Edukacji Narodowej,Warszawa, 1935, s.349.

7 B. Bieńkowska ..., o. C., 5, 137 .

8 Ustawodawstwo szkolne..., $5,212-213$.

9 Zbiór przepisów administracyjnych Królestwa Polskiego. Wydział Oświecenia, t. 2, Warszawa 1657, s. 303.

10 K. Opazek. Nauka w Polsce okresu Oswiecenia, w: Polska w epoce Oswiecenia, Warszawa 1971, s. 251.

11 Tamże, s. 71.

12 M. Lodyríski, Wpływ wytycznych Kumisji Edukacji Narodowej na politykę ksıęstwa Warszawskiego i Królestwa Polskiego, w: Z dziejów ksiażki i bicliotek w werszawie, Warszawa 1961, s. 94.

13 Historia wychowania, Pod red. t. Kurdybachy, t. 2, warszawa 1967, s. 152 i nast.

14 Ustawodawstwo szkolne...., s. 14.

15 s. Truchim, Szkice z dziejów szkkalnictwa i kultury, Poznań 1930. 
16 M. kodyński. Materiały do dziejów państwowej polityki biblioteczatej M Kęstwie Warszawskim i Królestwie Polskim, Wrocław 1958, 5. VII.

17 M. Lodyński. Organizacia bibliotek szkolnych w Księstwie Warszawskim i Królestwie Polskim w. latach 1807-1831, "Przegląd biblioteziny" 1960, z. 1, s. 2.

18 Tamze, s. 28.

19 L.Falkowska, $Z$ dziejów polskich bibijiotek szkolnych. Warszawa 1366: s. $19-20$.

20 M. Łodyński, Organizacja..., s. 15.

21 Modyruki. Materiały do.... s. 140.

22 M.todyiski, Rola bitilotek szkolnych w życiu kulturalnym Królestwa Polskıego /1815-183i/. "Przegląd biblioteczny" 1957: z 2/3, S. 157 .

23 Historia wychowania, t.2. s. 328.

24 Tamże, t. $3, c z .1,5.431$.

25 K. Konarski. Nasza szkoła, Warszawa 1932, s. 293.

26 Tamże, 5.294.

27 H. Eąbrowski, Alaksander rielopolski, t.2, /Dokumenta/. Kraków $1978,5.279-358$.

20 Tamie, s. 352-354.

29 Zróciła do dżejów wychowania i myśli pedagogicznej, t. 2, Warszawa 1965, s.38ن-381.

30 Nasza walka o szkołę polską. 1901-1917, t.1, Lwów 1932, 5.123. 31 H.Falkowska, z. dziejów..., s.42.

32 K. Konarski, Ruch stowarzyszeniowy w Warszawie w latach $1906-$ 1915, w: Z dziejów ksiazki i bibliotek w Warszawie, Warszawa 1961, s. 408 .

33 R. Wroczyński, Ruch oświatowy w Królestwie Polskim w początkach Xx wieku, w: Z dziejów ksiązki i bibliotek w Warszawie ... . 5.232.

34 Z. Rabska, Ze wspomnień o pracy w czytelniach wTD, w: Z dziejów ksiacki i bibliotek w Warszawi.e..., s.455.

35 Tamze. 
36

R. Wroczyriski, Ruch oświatowy ..., 5.230-283.

37 Historiá Polski, fod red. T.Manteuf́fla, t..2, c.z.3, s.135.

38 H. Falkowska, Z dziejów ..., s. 27.

39 S. Truchim, Szkice z dziejów... s.80-81.

40 H. Falkowska, $z$ dziejów.... s. 30.

41 Zarys pedagogiki, Red. B. Suchodolski, t.1, Marszawa 1962. 5. 151.

42 H.Falkowska, z dziejów.... s. 48.

43 Tamże, s.66.

44 Z.Dylik, Biblioteki szkolne w polskim systemie mencwawczym,

"Kwartalnik pedagogiczny" 1968, ir 2, 5. 138. 